$$
\begin{aligned}
& \text { الباثولوجيا ــكلية الطب البيطرى ـ ـجامعة أسيوط. }
\end{aligned}
$$

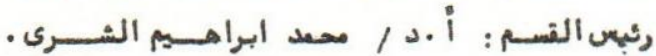

$$
\begin{aligned}
& \text { بـ راسة مناعية هستوكيميائية وهستو باثولوجيا عن الاد ينو مانزس } \\
& \text { فو الأفنسام } \\
& \text { مدمد الشهرى.، معفود عبد الظاهر }
\end{aligned}
$$

تم ملاحظة حالة اد ينوماتوزس فى أغنام من مد يرية الجبيزة وكانت الحالة تمثل التهاب رئســـــــوى

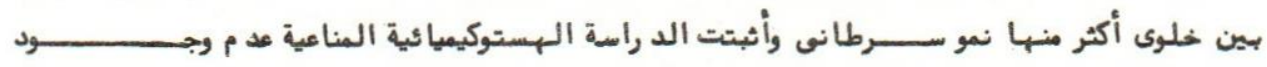

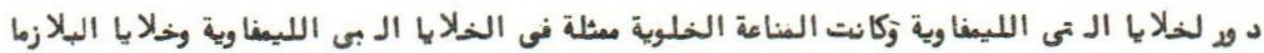

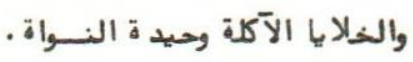


Dept. of Pathology,

Faculty of Vet. Mede, Assiut University,

Head of Dept, Prof. Dr. M.L. El-Sherry.

\title{
IMMUNOHISTOCHEMICAL AND HISTOPATHOLOGICAL STUDY OF SHEEP PULMONARY ADINOMATOSIS IN A RECORDED CASE \\ (With 9 Figures)
}

\author{
By
}

\author{
M.I. EL-SHERRY and A.Z. MAHMOUD \\ (Received at 20/10/1982)
}

\section{SLAMARY}

\begin{abstract}
Sheep pulmonary adenomatosis had been observed from El Giza Governate. The process was interstitial pneumonia rather than neoplastic growth. Immunohistochemical studies demonstrated that, T-lymphocytes play no roles in the immune process of sheep pulmonary adenomatosis observed. Cellular immunity was represented by B-lymphocyte, plasma cells, and mononuclear macrophage reaction.
\end{abstract}

\section{INTRODUCTION}

Many aspects in the nature of sheep pulmonary adenomatosis are still controversal. While STUNZI, HEAD and NELLISED, 1974 had classified sheep pulmonary adenomatosis broncho-alveolar adenocaricinoma. They referred that epidiomologically sheep pulmonary adenomatosis behaves like an infectious disease and may be associated with a virus. On other hand many authors as early as MITCHELL (1915); COWDRY (1925); DEKOCK (1929) and STEVENS (1957) had regarded pulmonary adenomatosis as an interstitial pneurnonia of sheep in which there is mainly proliferation of alveolar epithelium resembling adenomatous growth, with secondary metastasis in the regional lymph node. DURAN-REYNALS, JUNGHERR, CUBA-CAPARO, RAFFERTY, and HELMBOLDT, (1958) considered the different forms of sheep pulmonary adenomatosis in various countries (Africa; ROBERTSON 1904, America; MARSH 1923-1929, Iclanda; DUNGAL 1938, France; LUCAN 1944) as a complex of reiated diseases ranging from infiltrative pneumonia to metastasizing carcimoma.

No concrete prove for the virus nature of the disease has been done up till now. Evidence of viral etiology was concluded from experimental infection by cohapitation, droplet infection (WANDERA 1971 and TUSTIN 1980), by implantation of intact cells (COETZEE and VERWOERD 1976) and by inoculation of cell free extract (VERWOERD , MICHELE, and TUSTIN, 1980). VERWOERD et af. 1980 concluded on the basis of experimental inoculation of microsomol fraction the presence of membran RNA virus similar to type $B$ and $D$ retroviruses.

With the modern histochemical differentiation of the lymphocytic populations into B and $T$ cells, the necessity arises for recatologing of the disease of our domestic animals as regard to this immunological aspects (AGEEV, 1976). The immunology of sheep pulmonary adenomatosis is still unfully studied problem.

The aim of this work is to study some histopathological and immunohistochemical aspects of recorded sheep pulmonary adenomatosis in El-Giza governate Egypt.

\section{MATERLAL and METHODS}

Material for this observation were obtained during the histopathological exaraination of H \& E 7 U paraffin sections of all the parenchymatous organs; carcuss and visceral lymph node six adult sheep and six adult goat. The animals were purchased from Embaba Market El-Giza Governate, sheep pulmonary adenomatosis were discovered in the lung of one sheep. 
The following histochemical reaction was carried out: Alkaline phosphatase reaction (GOMORh, 1977) was carried to detect lymphocytes in transformation. PAS reaction (Aiter Mc MANUS, 1948) were performed to detect PAS + ve B-lymphocytes. Methyl green pyronin (BANCROFT and STEVENS, 1975) was carried out to detect plasma cells \& pyroninophilic B lymphocytes. Acid phosphatase enzyme (GOMORI, 1977) were used for T lymphocytes and macrophages. The connective tissue stains (Malory) Heidenhain trichrome stain, GASON, 1950) was performed for detection of the types of fibers in the c.t present. Gemsa stain (BANCROFT, 1977) was performed to survive the presence of inclusion bodies.

\section{RESULTS}

\section{Gross appearance:}

The lesions appeared in the form of small nodules in the two third of the ventral portion of the lungs. Small nodules were about $1.2 \mathrm{~mm}$. in diameter, larger nodules not exeeded $5 \mathrm{~mm}$. The nodules were ranging from gray bl ue to gray white in colour and of solid consistancy, on cut section they were of whitish grey colour. The nodules were projecting among the normal parenchyma or those suffering emphysema or atelectasis. Mucous exudat were seen in the bronchi. No metastasis has been observed in the bronchial lymph node.

\section{Histopathology:}

The early lesions appeared in the form of microscopic nodules about $1-2 \mathrm{~mm}$. in diameter scatiered in the pulmonary lobules (Fig. 1). These nodules were formed by finger like hyperplastic projections of the alveolar wall. The alveolar epithelium was transformed into tall columonar epithelium covering these finger like branched projections on a connective tissue cor (Fig. 2). The columner cells showed quite resting vesicular nucleus. Many alveoli were dilated and contained the different cut sections from these papilliferous growths. Interstitial spaces thickened by fibrous c.t. The c.t. core of many hyperplastic pappillae was infiltrated by polymorph nuclear leucocytes, these expanding nodules were exerting pressure atelectasis to the surrounding normal alveoli, many of which containing monocytic infiltration. In larger nodules, the polymporph nuciear infiltration became more intensive, so that it caused destruction of this finger like projection (Fig. 3). The majority of bronchiolesshowed the papilliferous growth (Fig. 4). The lamina propria of the bronchioles were infiltrated with few amount of lymphocytes.

In advanced lobular affections these nodules coalesed together to involve all the lobules leaving inbetween slightly compressed alveoli heavily infiltrated by mononuclear cells. Some of these nodules showing the typical adenomatous growth as adeni of different shapes and sizes lined by tall columonar epithelium and separated by wide c.t. stroma (Fig. 5). This stroma in many parts was infiltrated by lymphocytes and plasma cells (Fig. 6). At this stage characteristically was the formation of peribronchial lymphoid follicles. Large bronchioles showed catarrhal bronchitis. Most of the bronchi and bronchioles were involved in the process of papilliferous growth.

In a late stage there was extensive fibrosis. The c.t. was heavily infiltrated with lymphocytes and plasma cells. The c.t. pressed upon some alveoli causing its collapse and disappearance.

In the bronchial lymph nodes no metastasis could be detected. The subcapsular sinus and lateral sinuses were normal. The follicles were rion germinating follicles. The follicles and paracortex were mainly made of prolymphocytes. The medullary cords were mostly consists of prolymphocytes. The sinus macrophages were moderately activated.

PAS positive lymphocytes were demonstrated among the infiltrating cells. The papilliferous growth arising from bronchi contained mucin producing cells (Fig. 7), while the adenomatous growth arising from alveoli showed no mucin producing cells. No destruction of the basement membrane were observed. PAS positive lymphocytes were found in the medullary cords of the bronchial L.N. beside plasma cells.

\section{Acid phosphatase reaction:}

No acid phosphatase positive $T$ lymphocytes was discovered in the lung or bronchial lymph nodes. Only collection of large macrophages were acid phosphatase positive (Fig. 8).

\section{Alkaline phosphatase:}

Alkaline phosphatase positive lymphocytes were demonstrated in the peribronchial lymph follicles (Fig. 9). Also sporadic infiltrating lymphocytes showed the reaction. The bronchial lymph nodes were free from alkaline phosphatase. 
SHEEP PULMONARY ADINOMATOSIS

\section{Methyl green pyronine:}

The reaction confirm the differentiation of the pyroninophilic infiltrating lymphocytes in the cot. cores of the adenomatous growths into plasma cells. Also the reaction excluded the presence of any nucleoli in the opithelium rells of the adenomatous and papilliferous prolifration.

The medullary cords of the bronchial lymph node showed millk differentiation into pyroninophilic B and plasma cells.

Mallory Heidenhain trichrome reaction: The reaction showed that the c.t. cores of the papilliferous growth were mainly made of collogen fibers. No elastic or reticular fibers were detected.

\section{DISCUSSION}

The histopathological picture of sheep plumonary adenomatosis discovered in El-Giza Governate was that mainly of epithelial proliferation associated with secondary growth of c.t. in form of hyperplastic papilliferous growth or adenomatous pattern of growth of broncho - alveolar origin. In our openion it is a form of inflammatory hyperplasia more or less resembling the polyoid nature of the productive inflammation of the mucous membrane in general. The inflammatory nature is confirmed by the infiltrating polymorph, B lymphocytes, plasma cells and peribronchial follicular hyperplasia, and the chiaracteristic massive aggregation of mononuclear macrophages. No evidence of neoplastic nature were observe. All the epithellal tell nuclei were resting, no mitotic figures were observed. The basement membrane were intact. No invassive growth or metastasis were detected. The epansive nodutar pattern of the early lesions although in common with adenoma type of growth but also related to the local productive inflammation. The adenomatous type of growth in our openion arised from metaplasia of the squamous epithelium lining the alveoli into cubiodal and high columonar epithelium. The pressure of the extensively proliferating septal connective tissue stroma causing either collapse or cystic dilatation of these adeni.

Thus the above result do not conicided with the classification of FAO (STUNZI et al. 1974) as broncho-alveolar neoplasia. Our result confirm the openion that pulmonary adenomatosis is a type of interstitial pneumonia (MITCHELL, 1915; COWDRY, 1925; DEKOCK, 1929 and STEVENS, 1957). Although the three factor of the chronic interstitial pneumonia were present i.e. epithelial proliferation, c.t. proliferation and peribronchial follicular hyperplasia but differential for sheep pulmonary adenomatosis was the extensive papilliferous and adenomatous growth of the epithelium (RAJYA \& SINGH, 1964; SASTRY; NARAYANA; RAMA and CHRISTOPHER, 1965, and NOBEL, 1968). The c.t. proliferation was secondary to the eprhelial growth. This is a differential from maedi in which the main microscopic lesions were a considerable proliferation of motsenhymal tissue causing thickening of the alveolar sepra but no epithelization. Inculsion bodies are characteristic. (SIGURDSSON, 1954). No inclusion bodies were detected in our case. The significance of the peribronchial lymph folliclular hyperplasia in the picture of sheep pulmonary adenomatosis was controversal. While MITCHELL, 1915 describe the peribronchial and perivascular lymphoid hyperlasia to be the most obvious early microscopic lesions. COWDRY, 1925 on the other hand dismissed the occasionally occuring peribronchial lymphoid infiltration as not being in excess of what may be seen in normal sheep.

DEKOCK, 1929 found complete absence of lymphoid follicles in the majority of cases examined. The peribronchial, and perivascular lymphoid hyperplasia without epithelization is differentrial for Mountona Progressive pneumonia (MARSH, 1923; COWDY and MARSH 1927; DUNGAL, et al, 1938). In our result peribronchialhyperplasia is of secondary significance as it was only associated with advanced lesions.

The histochemical survey demonstrated absence of acid phosphatase positixe lymphocytes either in the pulmonary lesion or in the bronchial lymph nodes. Only macrophages carrying pigments were acid phosphatase positive.

CATOVSKY, et al., (1974) proved that, the most characteristic histochemical feature for $T$ lymphocytes was prominant positive reaction for acid phosphatase and negative PAS. This means that $T$ lymphocytes play no roles in the immune process of sheep pulmonary adenomatosis observed in our material.

Cellular immunity was represented by macrophage reaction in form of massive presence of mononuclear cells in the pulmonary tissues surrounding the growing nodules and in form of polymorph infiltration of the adenomatous growth.

Assiut Vet.Med.J. Vol. 11, No. 22, 1984. 
In our openion the mononuclear macrophages play the main role in the cellular immunity as they appear early in the lesion, constantly described with sheep pulmonary adenomatosis by many authors (ROBERTSSON, 1904; MITCHELL, 1915; COWDRY, 1925; DEKOCK, 1929 and SIGURDSSON, 1954), and probably, the polymporph may be a reaction to secondary bacterial infection.

It is prominant from this observation that B lymphocytes and plasma cells share the major role in the process of immunity of sheep pulmonary adenomatosis observed in our material. The majority of infiltrating lymphocytes were PAS positive and negative for acid phosphatase (CATOVSKY et al., 1974). Plenty of plasma cells were founded between the infiltrating lymphocytes, representing the end stage of B lymphocytes differentiation.

Alkaline phosphatase positive lymphocytes found in the peribronchial lymph follicles, represent lymphocytes in transformation (A.K. AGEEV, 1976). Bronchial lymph nodes showed medullary cord differention into B lymphocytes and plasma cells.

\section{REFERENCES}

Ageev, A.K. (1976): T and B lymphocytes distribution in the organism, functional morphological characteristic and significance. Arch. Pathology Vol. 12, 3-11.

Bancroft, D.J. and Stevens, A. (1975): Histopathological stains and their diagnostic uses (Unna - pappenheim stain), p.p. 119-121.

Bancroft, D.J. and Alan Stevens (1977): Alkaline phosphatase Gomori Calcium methods. Acid phosphatase Gomori lead method. Theory and practice of histological techniques pp. 290-291.

Bancroft, D.J. and Alan Stevens (1977): Histopathological stains and their diagnostic uses, Giemsa methods for chromaffin cell granules $92-93$.

Catovsky, D., Galetto, J.O., Okes, A., Milliani, E. and Galton, A.G., Cytochemical profile of B and T leukaemic lymphocytes with special reference to acute lympholblastic lenkaemia. J. Clinical pathology Vol.27 p.267-771.

Coetzee, S., Els, M.J. and Verwoerd, D.W. (1976): Transmission of jaagsiekte ovine pulmonary adenomatosis by means of a permanent epithelial cell line established affected lungs. Onderstepoort Journal of Vet. Res. 43, $133-142$.

Cowdry, E.V. (1925): Studies on the etiology of jaagsiekte 11- the origin of the epithelial proliferations and the subsequent changes. J. exp. Med. 42, 335-346.

Cowdry, E.v. and Marsh, M. (1927): Comparative pathology of such African Jaagsiekte and Montana Progressive Pheumonia of sheep 3. exp. Med. 45, 571-5.

Dekock, G. (1929): Are the lesions of Jaagsiekte in sheep in the nature of a neoplasm. 15th Ann. Rept. Dir. Vet. serv. south Afr. 611-961 (Cited by senseen, R. 1974).

Dungal, N. (1938): Epizootic adenomatosis of the lungs of sheep its relation to verminous pneumonia and Jaagsiekte. proc. Ray, Soc. Med., 31, $499-505$.

Duran, Reynals, F.; Jungherrm F., Cuba Caparo, A.; Rafferty, K.A. $\quad$ and Helmoboldt, C. (1958): Pulmonary adenomatosis complex in sheep. Ann. New York Acad. Sci. 70, 726-741.

Lucan, F. (1944): Research on a disease of sheep commonly known as Bouhite. Bull. Acad. Vet. Fry 17, $144-146$. (Vet. Bull, 17, 48).

Mc MaNus, J.F.A. (1948): Periodic acid Schiff reaction. Stain technol. $23: 99$.

Marsh, M. (1923): The bacteriology of progressive pneumonia in sheep. J.A.V.M.A. 62, $458-473$.

Marsh, M. (1929): Some obscure disease of sheep J.A.V.M.A. 74, 724-734.

Humason, G.L. (1961): Mallory Heidenhain trichrome Stain = Rapid one-step method (Cason 1950) Animal tissue techniques 151.

Mitchell, D.T. (1915): Investigations into Jaagsiekte or chronic catarrhal-pneumonia of sheep. 3rd and 4th Report. Director. Vet. Education research union S. Africa.,pp. 585-614. (Cited by Stamp, J.T. and Nisbet. D,I. 1963).

Nobelm T.A. (1968): Pulmonary adenomatosis (Jaagsiekte) in sheep with special reference to its occurance in Israel. Israel Vet. Med. Assoc. 62, 759-762.

Rajya, B.S. and Singh, C.M. (1964): The pathology of pneumonia and associated respiratory disease of sheep and goats. 1. Occurance of Jaagsiekte and maedi in sheep and goats in Indian. Am. J. Vet. Res. 25, 61-67. 
Ropertsson, W. (1904): Jaagsiekte or chronic Catarrhal pneumonia of sheep. J. Comp, Path. 17, 221-224.

Sastry, G.A.; Narayana, J.V.; Rama Ras, R. and Christopher, J. (1965): Occurance of pulmonary adenomatosis (Jaagsiekte) in sheep of Andhra Pradesh. Indian Vet. J. 42, 25-55.

Sigurdsson, B. (1954): Maedi, A slow progressive Pneumonia of sheep: an epizotological and pathological study. Brit. Vet. J. 110, 255-270.

Stevens, A.J. (1957): Respiratory diseases of sheep. Vet. Bull. 39, 747.

Stunzi, M.; Mead, K.W., Nielsen, S.W. (1974): Bull. of international Histological classification of tumours of domestic animals $50,9-19$.

Tustin, R.C. (1980): Etiology of Jaagsiekte experimental transmission to lambs by means of cultured cells as homogenates. Onderstopoort Journal of Vet. Research. 47.

Varcuaerd, W.; Anna lise William-son and ethel-Michele De Villiers (1980): Etiology of Jaagsiekte: Transmission by means of subcellular actions and evidence for the involvement of a reterovirus. Ondertepoorth $\mathrm{J}$. Vet. Res. 47, 275-280.

Verwoerd, D.W., Devilliers, ethel-Michele and Tustin, R.C. (1980): Aetiology of Jaagsiekte: experimental transmission to lambs by means of cultured cells and homogenates. Onderstepoort. Journal of Vet., Res. 47, $13-18$.

Wandera, J.G. (1971): Sheep pulmonary adenoma in; Brandly C.A. \& Cornel Jus, C.E. (Ed.) Adiance Veterinary Science and Comparative Medicine 15, 21 New York \& London: Academic Press.

\section{BESCRIPTION OF FIGURES}

Fig. (1): Showed lesions in the form of microscopic nodules (M.E. $6.3 \times 10$ ).

Fig. (2): Showed Finger like projection of papilliferous growths (H.E. $16 \times 10$ ).

Fig. (3): Showed destruction of this finger like projection by polymorph nuclear cells. (M.E. $16 \times 16$ ).

Fig. (4): Bronchioles showed the papilliferous growth.

Fig. (5): Nodules showing adenomatous growth. (M.E. $16 \times 10$ ).

Fig. (6): Showing stroma infiltrated by lymphocyes \& plasma cells. (M.E. X 250).

Fig. (7): Showed bronchi with papilliferous growth contained mucine producing cells. PAS $(10 \times 10)$.

Fig. (8): Showed collection of acid phosphatase positive large Macrophages (Gomori 63 X 10).

Fig. (9): Showed alkaline phosphatase positive lymphocytes in the peribronchial lymph follicles. (Gomori $6 \times 10$ ). 


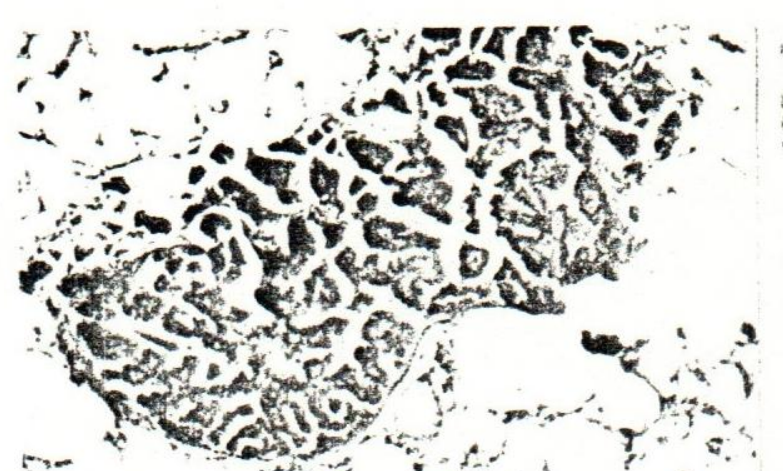

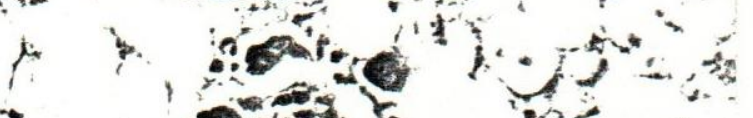

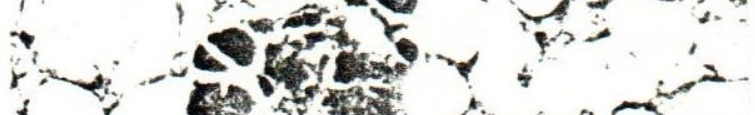

ind

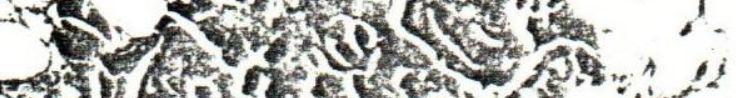

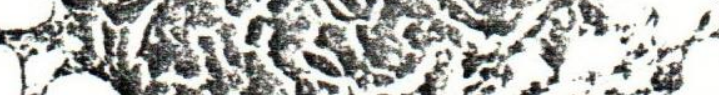

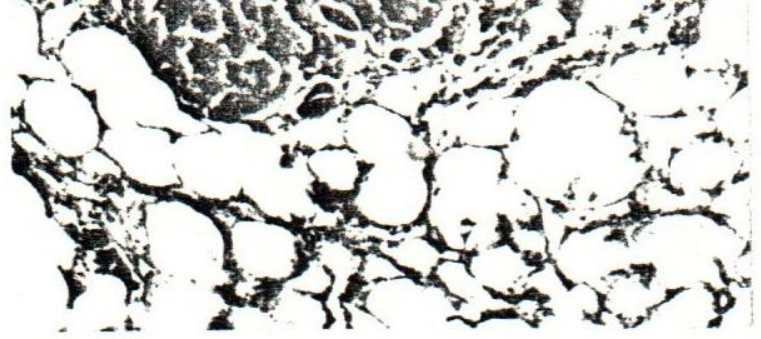

\section{Fig. (I)}

-

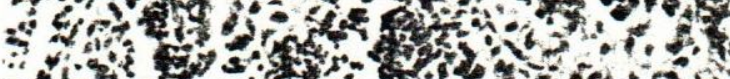
7 t

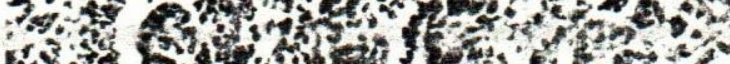
15. So

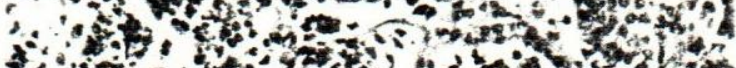

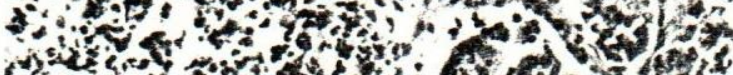

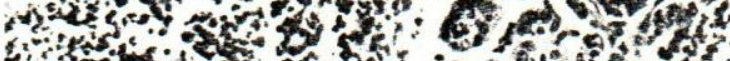
4. (a)

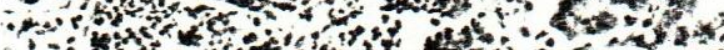

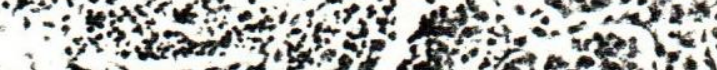
an - M

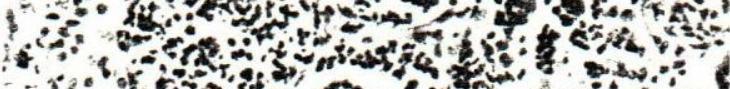
* $\therefore$ a 200 a a o o $\therefore$, nd

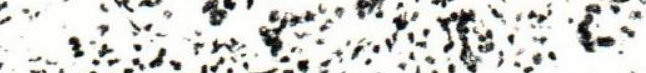

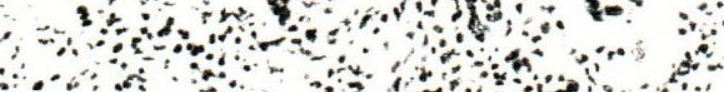
Fig. (3)

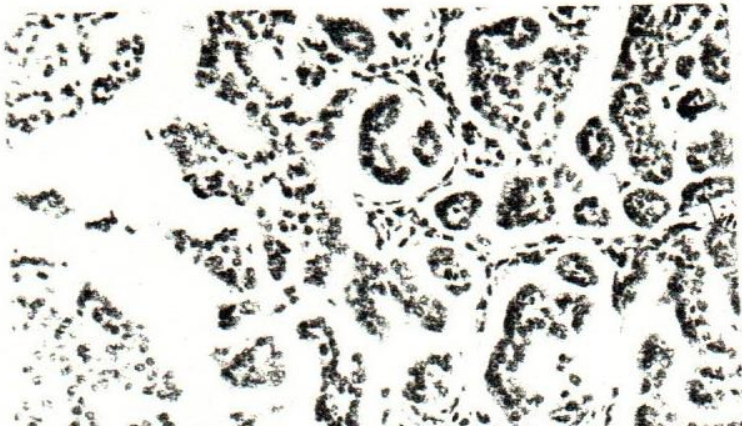

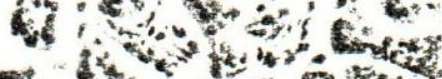
"

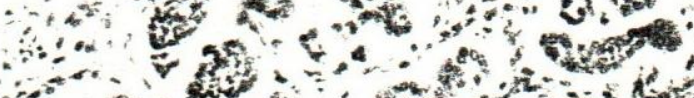

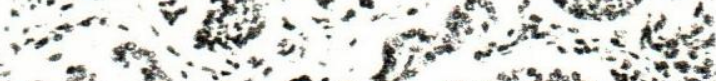
수

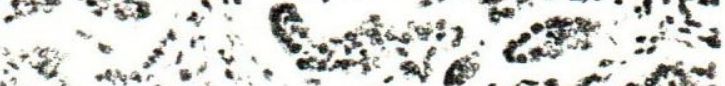

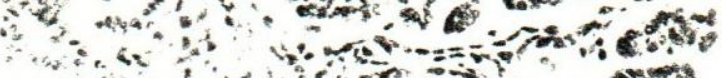

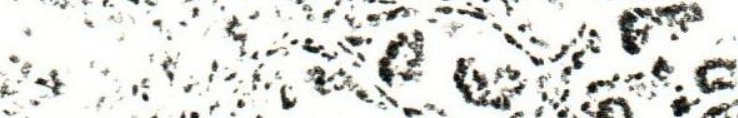

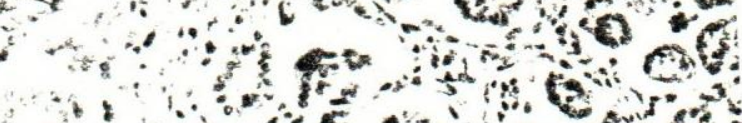

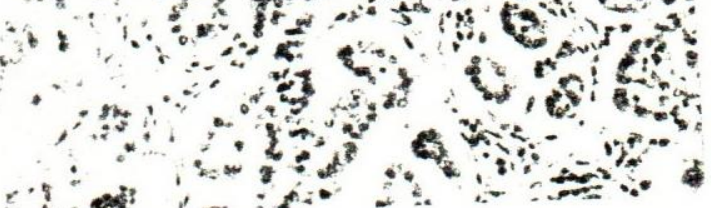
Fig. (2)

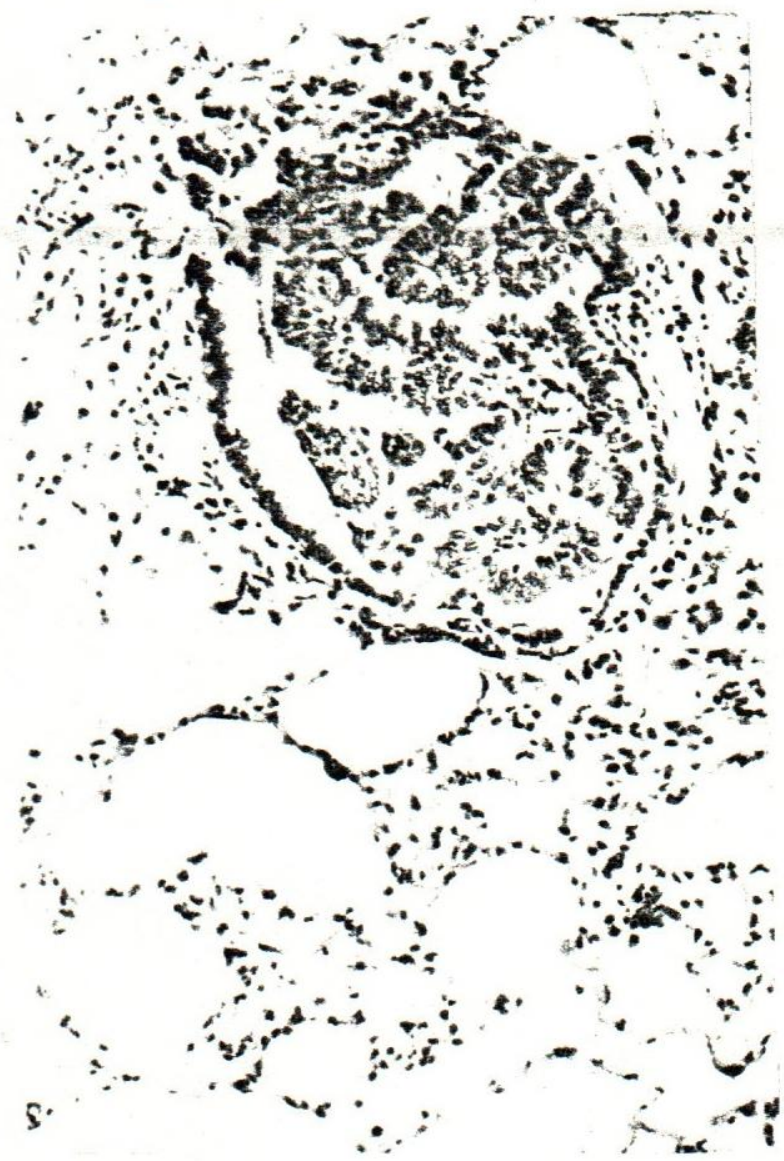

Fig. (4) 


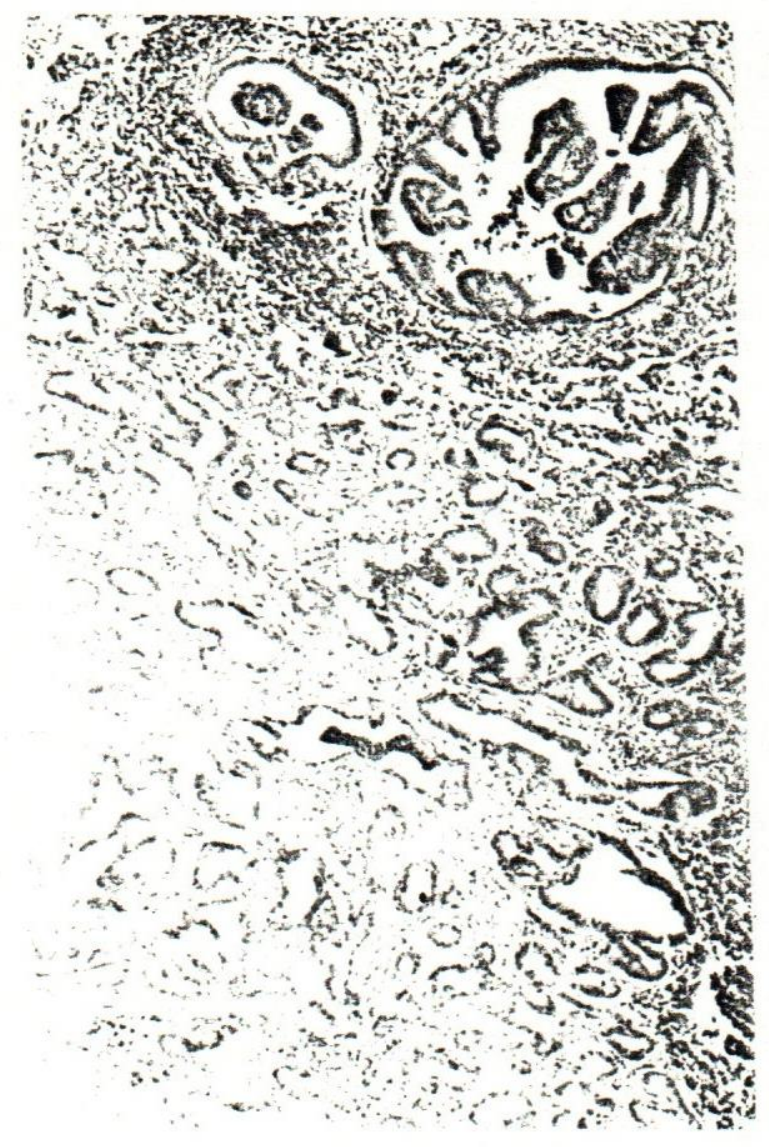

FIG. (5)

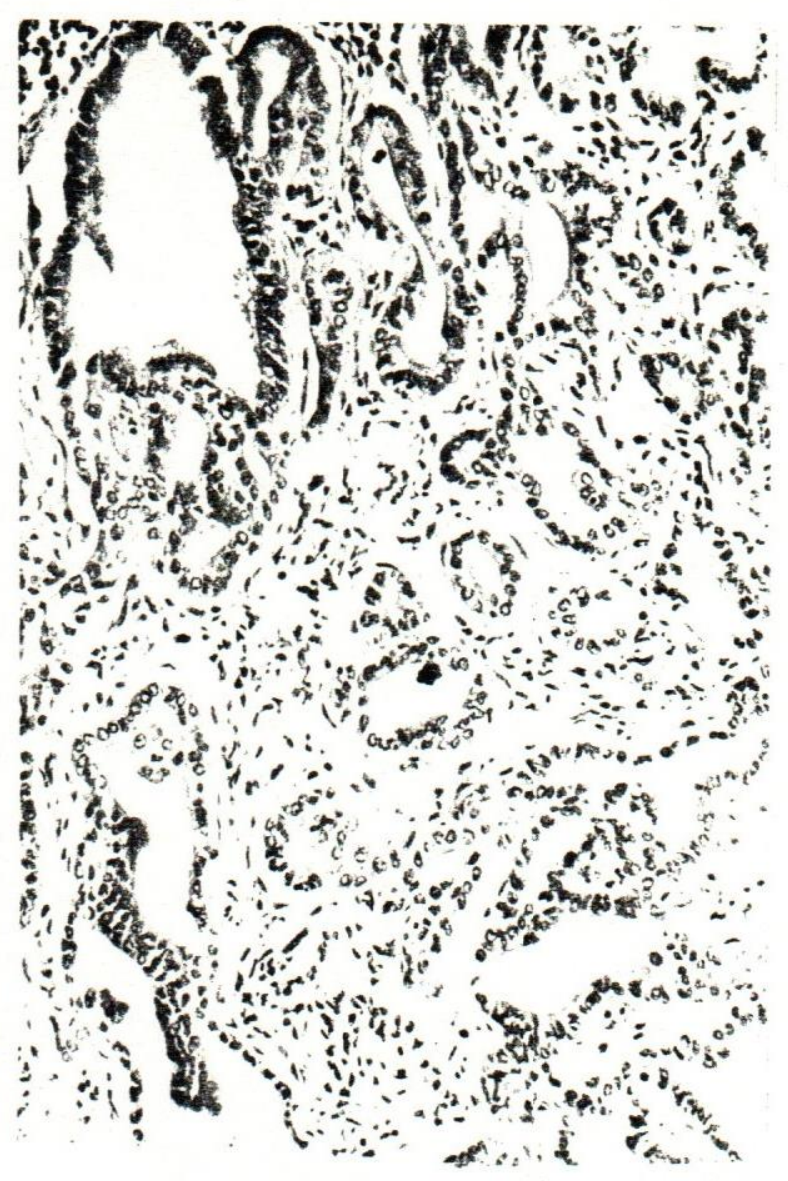

FIG, (6)

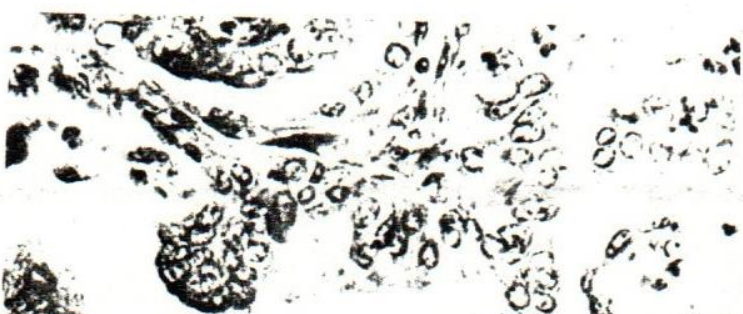

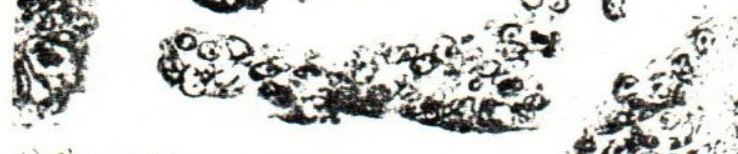

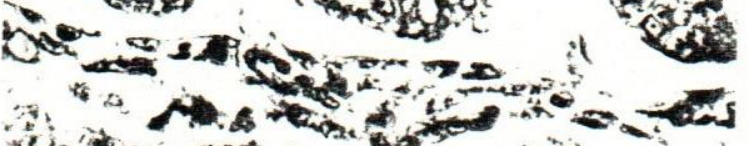

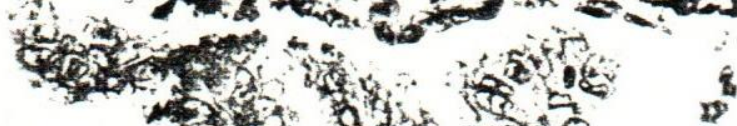

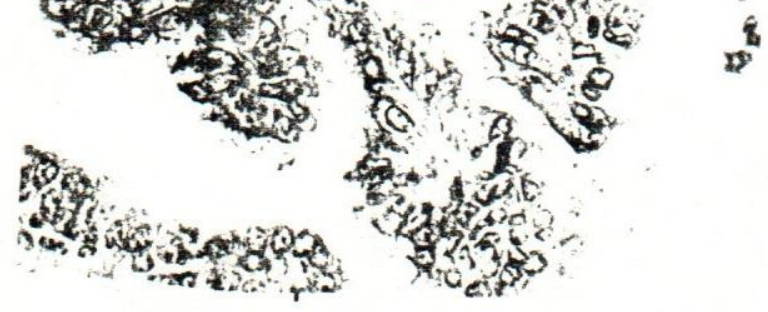
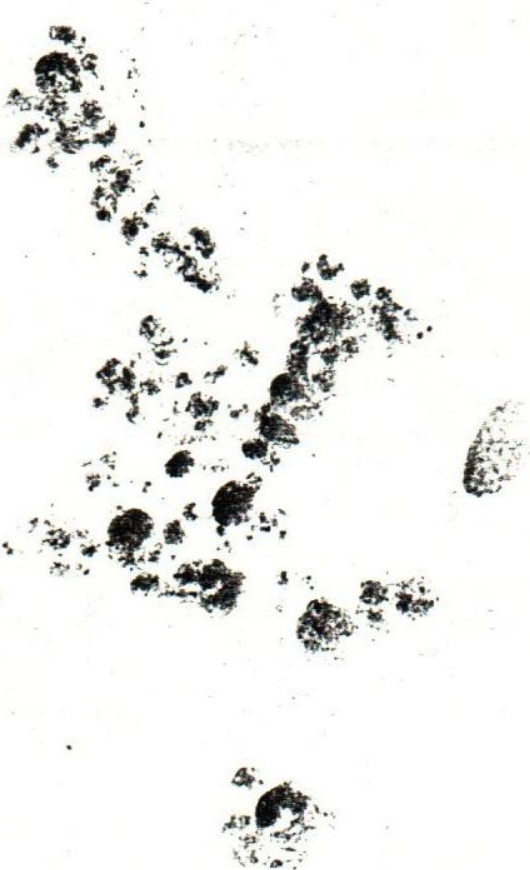


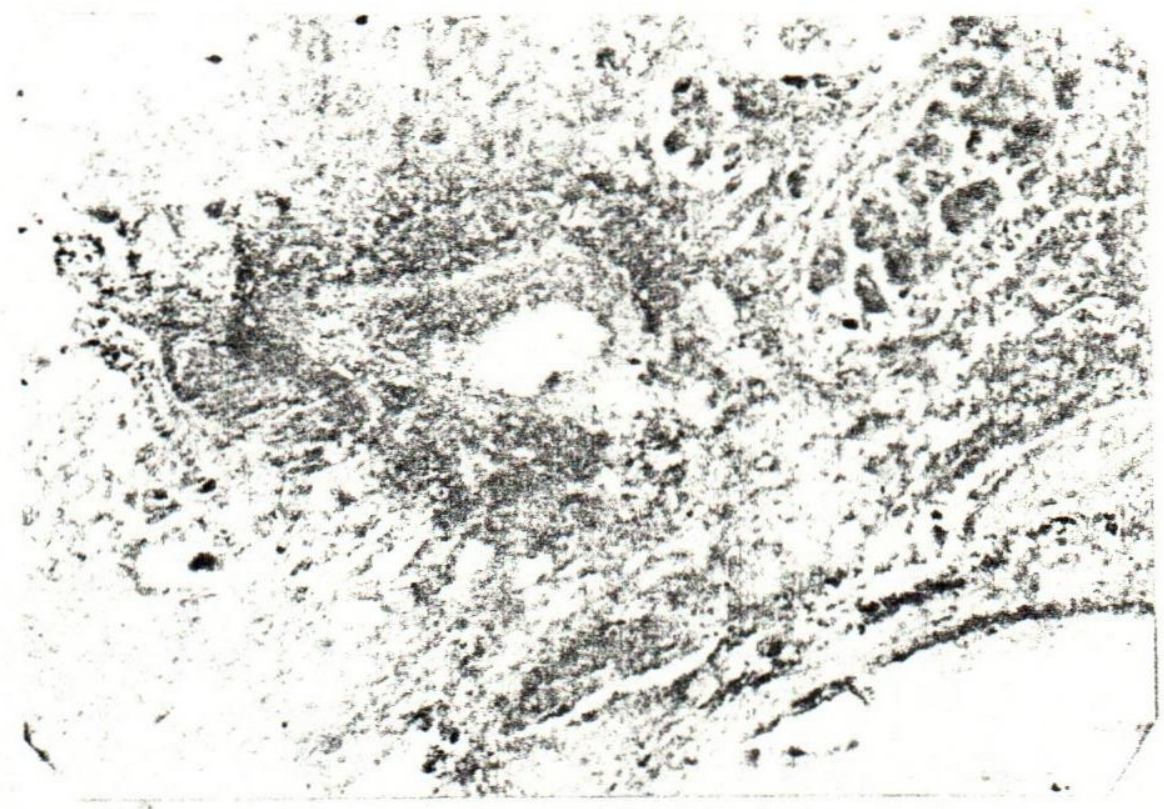

FIG, (9) 
